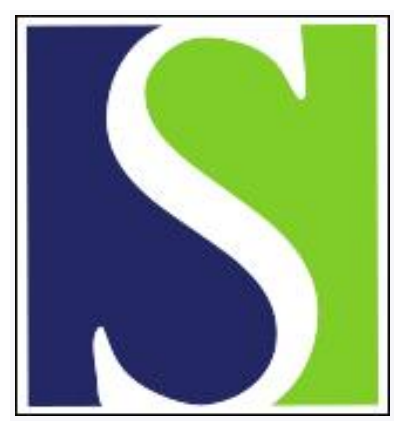

Scand J Work Environ Health 1983;9(2):136-139

https://doi.org/10.5271/sjweh.2433

Issue date: Apr 1983

Methods of hazard analysis applied in the light metal industry. by Saarela KL

This article in PubMed: www.ncbi.nlm.nih.gov/pubmed/6648410

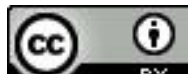




\title{
Methods of hazard analysis applied in the light metal industry
}

\author{
by Kaija Leena Saarela
}

\begin{abstract}
SAARELA KL. Methods of hazard analysis applied in the light metal industry. Scand $j$ work environ health 9 (1983) 136-139. There is at present a wide variety of methods to be used for the identification and evaluation of hazards. The information resulting from a hazard analysis can be used to develop measures for either the elimination or the control of hazards. Hazard analysis has not yet been used very widely in industry. More information is needed, eg, about the applicability of methods to different types of systems. A joint project, where hazard analysis was applied to various fields, was carried out in the Nordic countries. One part of this project concentrated on the light metal industry. A trial was carried out on a production line for which man-machine tasks play an important role. Job analysis was selected as the means of revealing possible accidents. On the production line this procedure turned out to be a good point for systematic investigation. The selection of the methods to be applied within a system should be done carefully. It is important that sufficient knowledge is available both about the characteristics of the system and about the existing methods. The rapid increase of information in this area makes it possible to put hazard analysis to better use in industry.
\end{abstract}

Key terms: job analysis, safety analysis.

Safety analysis methods provide useful tools for revealing possibilities for occupational accidents (2). The analysis produces material for planning preventive measures.

The selection of methods is greatly affected by the nature of the object of analysis. In very complicated systems, for which the consequences of accidents can be considerable, more attention should usually be given to the reliability of the system. In more general systems where man-machine tasks play an important role, methods which pay more attention to the work itself are useful. The revealing of possible accidents can, eg, be connected to a detailed job analysis. If some kind of evaluation is considered necessary, there are also methods and techniques suitable for this purpose. It is common to apply several methods to the same object concurrently. The methods have to be selected carefully, and the goals of the analysis must also be taken into account. 1 Department of Occupational Safety, Institute
of Occupational Health, Helsinki, Finland.

Reprint requests to: Ms KL Saarela, Institute of Occupational Health, Laajaniityntie 1, SF01620 Vantaa 62, Finland.
This presentation concentrates mainly on job analysis and its potential uses in the identification of hazards. The great advantage of job analysis is the ease with which it can be applied. In connection with a SCRATCH project (SCRATCH = Scandinavian risk analysis technology cooperation), among other things, methods based an job analysis, such as work safety analysis (8) and ergonomic job safety analysis (3), have been applied and developed. The ergonomic job safety analysis will be described later in more detail. An example of its application on a production line in the light metal industry is also included. Job analysis is also a part of the MMSA (Man-machine systems safety analysis) procedure (7). Methods based on job analysis are the most useful when applied to systems which include repetitive tasks.

\section{Ergonomic job safety analysis}

Ergonomic job safety analysis has been developed at the Institute of Occupational Health on the basis of the ergonomic accident theory (5). The method involves the observation of the course of each job. 
Information is collected by the use of formats and checklists. Attention is also paid to possible deviations from normal routines. Photographs and videotapes can be used as aids. Each step of every task has to be investigated in order that possible injuries or damages can be detected.

The method also includes a checklist with a scoring system. The checklist can be applied in the metal industry to estimate the level of accident risk at the object of investigation. The background of the development of the checklist, among other things, comprises previous studies carried out in the metal industry by the Institute of Occupational Health (6).

\section{Experiences}

The applicability of the ergonomic job safety analysis was investigated in practice on a production line in the light metal industry. The production line manufactures 200-1 receptacle barrels. The number of workers is about 14 persons, and their tasks consist mainly of moving the materials, starting the machines, and controlling and maintaining some automatic functions. According to statistics (1979 and 1980), the number of injuries is about nine per year.

Each job was analyzed in detail. Information was collected by observation, and,

Table 1. Safety analysis of the job of seaming a normal type of barrel in a barrel factory.

\begin{tabular}{|c|c|c|c|c|c|c|c|c|}
\hline & $\begin{array}{l}\text { Steps of } \\
\text { tasks }\end{array}$ & $\begin{array}{l}\text { Object } \\
\text { of work }\end{array}$ & $\begin{array}{l}\text { Machines, } \\
\text { facilities, } \\
\text { etc }\end{array}$ & $\begin{array}{l}\text { Environ- } \\
\text { ment }\end{array}$ & $\begin{array}{l}\text { Human } \\
\text { factors }\end{array}$ & $\begin{array}{l}\text { Possibilities } \\
\text { for accident } \\
\text { occurrence }\end{array}$ & $\begin{array}{l}\text { Actions to } \\
\text { increase } \\
\text { safety }\end{array}$ & Comments \\
\hline 1 & $\begin{array}{l}\text { Assembly } \\
\text { of barrel } \\
\text { head-shell- } \\
\text { cover, } \\
\text { transfer to } \\
\text { the seamer }\end{array}$ & $\begin{array}{l}\text { Barrel } \\
\text { head } \\
\text { and cov- } \\
\text { er (diam- } \\
\text { eter, } \\
587 \mathrm{~mm} \text {, } \\
\text { weight } \\
3.3 \mathrm{~kg} \text { ) and } \\
\text { shell (dia- } \\
\text { meter } \\
587 \times \\
844 \mathrm{~mm} \text {, } \\
\text { weight } \\
12.5 \mathrm{~kg} \text { ) }\end{array}$ & $\cdot$ & $\begin{array}{l}\text { Noise, } \\
\text { rolling } \\
\text { shell, } \\
\text { piles } \\
\text { of head } \\
\text { and cov- } \\
\text { er sheets, } \\
\text { oil and } \\
\text { sealing } \\
\text { compound } \\
\text { on the } \\
\text { floor }\end{array}$ & $\begin{array}{l}\text { Obser- } \\
\text { vation of } \\
\text { machines, } \\
\text { selection } \\
\text { of the } \\
\text { right } \\
\text { sheet } \\
\text { (head or } \\
\text { cover) }\end{array}$ & $\begin{array}{l}\text { Cut caused by } \\
\text { a metal sheet } \\
\text { Contact with } \\
\text { falling objects } \\
\text { (barrel head, } \\
\text { shell or cover); } \\
\text { collapse of } \\
\text { piles; danger } \\
\text { of tripping; } \\
\text { failure in } \\
\text { assembly of } \\
\text { a barrel }\end{array}$ & $\begin{array}{l}\text { Use of gloves } \\
\text { (good resist- } \\
\text { ance against } \\
\text { cuts) } \\
\text { Protective } \\
\text { footwear, head } \\
\text { and cover sheets } \\
\text { in cages, allo- } \\
\text { cation of cages; } \\
\text { cleaning of the } \\
\text { floor (pre-- } \\
\text { vention of oil } \\
\text { leakage) }\end{array}$ & \multirow{3}{*}{$\begin{array}{l}\text { Gloves } \\
\text { worn on } \\
\text { the job } \\
\text { made } \\
\text { of very } \\
\text { thin } \\
\text { material; } \\
\text { ear pro- } \\
\text { tectors } \\
\text { used; } \\
\text { noise } \\
\text { abatement } \\
\text { to be } \\
\text { taken } \\
\text { into ac- } \\
\text { count in } \\
\text { connection } \\
\text { with each } \\
\text { measure }\end{array}$} \\
\hline 2 & $\begin{array}{l}\text { Start of } \\
\text { the seamer }\end{array}$ & • & $\begin{array}{l}\text { Seamer, } \\
\text { danger of } \\
\text { being pinch- } \\
\text { ed, rotat- } \\
\text { ing barrel, } \\
\text { spattering } \\
\text { of the } \\
\text { sealing } \\
\text { compound }\end{array}$ & $\cdot$ & $\begin{array}{l}\text { Full } \\
\text { protection } \\
\text { not } \\
\text { provided } \\
\text { by safety } \\
\text { devices }\end{array}$ & $\begin{array}{l}\text { Hand between } \\
\text { the barrel and } \\
\text { the machine; } \\
\text { touching of a } \\
\text { barrel rotating } \\
\text { in the machine; } \\
\text { barrel thrown } \\
\text { out of the } \\
\text { machine }\end{array}$ & $\begin{array}{l}\text { More effec- } \\
\text { tive protec- } \\
\text { tive equipment }\end{array}$ & \\
\hline 3 & $\begin{array}{l}\text { Stopping } \\
\text { of machine } \\
\text { (barrel } \\
\text { removed } \\
\text { automati- } \\
\text { cally) }\end{array}$ & $\cdot$ & $\begin{array}{l}\text { Disturbances } \\
\text { in removal } \\
\text { of the } \\
\text { barrel }\end{array}$ & $\begin{array}{l}\text { Conveyor } \\
\text { chute } \\
\text { situated } \\
\text { in wrong } \\
\text { place; } \\
\text { barrels } \\
\text { unable to } \\
\text { glide } \\
\text { easily; } \\
\text { noise }\end{array}$ & . & $\begin{array}{l}\text { Hands can be } \\
\text { pinched during } \\
\text { manual removal } \\
\text { of barrel from } \\
\text { machine; } \\
\text { hands can be } \\
\text { pinched be-- } \\
\text { tween barrels } \\
\text { during the } \\
\text { helping of the } \\
\text { barrels to } \\
\text { glide along } \\
\text { the conveyor } \\
\text { chute; barrel } \\
\text { falling }\end{array}$ & $\begin{array}{l}\text { Automatic barrel } \\
\text { removal more } \\
\text { reliable; } \\
\text { cleaning of the } \\
\text { conveyor chute; } \\
\text { making sure } \\
\text { that the con- } \\
\text { veyor chute is } \\
\text { in the right } \\
\text { place }\end{array}$ & \\
\hline
\end{tabular}

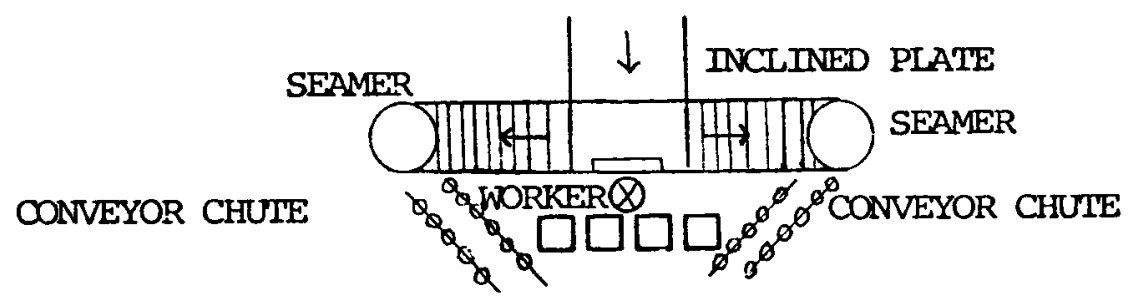

Fig 1. Layout of the workplace in which the job analysis of barrel seaming took place. 
if necessary, the material was completed by discussions with workers. Table 1 shows the analysis of a job on the production line, and fig 1 shows the layout of the workplace. Jobs could also be compared with each other with the help of estimations describing the levels of accident risks.

The total safety analysis also contained the investigation of other factors. The operation of the production line was studied by the detection of disturbances on the production line. Some environmental factors were also considered (noise, illumination and ventilation). Accidents which had occurred on the production line during the last two years were analyzed in more detail. Information about near misses was also collected.

Problems observed as the result of the analysis were described, and some information about their importance was also provided. Proposals were made for possible measures to eliminate or reduce the problems (4).

\section{Conclusions}

On a production line in which the work of individuals plays an important role, a detailed analysis of jobs forms a good base for the systematic discovery of possible accidents. The completed formats, which provide detailed information about the hazards and the potential accidents connected with each job, can be used for the development of preventive measures.

If other methods of safety analysis are considered which could be applied to a general production line, the method based on job analysis has many advantages. Methods (safety sampling, safetygram, etc) which focus, eg, on hazards and which do not consider the work itself separately can easily become too superficial. Such methods do not provide detailed information which might be needed for the detection of more complicated hazards and for the formulation of preventive measures.

Job analysis can be completed with a critical incident technique (1), with which information about past mistakes, hazards, and near misses are collected in interviews. The more the jobs vary, the more practical the use of interviews becomes as a means of collecting information.
Methods which make it possible to compare jobs with each other are useful in the detection of areas which require further attention. However it is important to be careful when these values are used because of their subjectivity.

One disadvantage of job safety analysis is that it requires much time. Other purposes also require job analysis (eg, occupational health services, work studies). One way that time can be saved is to combine these different purposes within the same investigation.

One critical phase of the application of the method is the detection of possible accidents. A checklist can be used as an aid, but care has to be taken that the use of the checklist does not automatize the process because creativity is after all the most important factor of this phase.

Another problem associated with this method is that the results are highly dependent on the abilities of the analyzer. The effect of the analyzer can be diminished by team work. It is also important to collect information from as many directions as possible (occurred accidents, near misses, etc).

If apparent problems can be seen or are suspected in specialized areas (eg, industrial hygiene, disturbances in production), it is useful to include the investigation of such obvious problems in the analysis.

The systematic investigation of different areas helps to produce a reliable and complete picture of the object. This picture forms a good base for the planning of measures for increasing safety.

\section{References}

1. Hammer W. Handbook of system and product safety. Prentice-Hall, Englewood Cliffs, NJ 1972. $351 \mathrm{p}$.

2. Saarela KL. Kirjallisuusselvitys turvallisuusanalyysin menetelmistä. [Literary survey of safety analysis methods]. Institute of Occupational Health, Helsinki 1980. $78 \mathrm{p}$. (Katsauksia 35).

3. Saarela KL, Häkkinen S, Saari J, Lahtela J. Ergonominen turvallisuusanalyysi - menetelmän kehittely metalliteollisuudelle [Ergonomic job safety analysis - Development of a method for the metal industry]. Institute of Occupational Health, Helsinki 1982. 61 p. (Tutkimuksia 186).

4. Saarela KL, Ukkola $\mathrm{K}$, Cavén T, Saari J, Lahtela J. Safety analysis of a production line manufacturing barrels: SCRATCH- 
project no 10. Nordforsk, Trondheim 1981. $28+16$ p.

5. Saari J. Ergonomisen tapaturmamallin kokeilu kahdella teollisuuden alalla [Application of the ergonomic accident theory in two types of industry]. Institute of Occupational Health, Helsinki 1977, 209 p. (Tutkimuksia 130).

6. Saari J, Lahtela J. Working conditions and accidents. A working paper for SCRATCHproject. Tampere University of Technology, Department of Mechanical Engineering,
Labor protection, Tampere 1978. 24 p. (Report 8).

7. Swain AD, Guttman ME. Handbook of human reliability analysis with emphasis on nuclear power plant applications. Draft report for interim use and comment. Sandia Laboratories, Albuquerque, NM 1980.

8. Tamminen J, Suokas J, Rouhiainen V. Instruction for work safety analysis: SCRATCH-project no 8. Technical Research Centre of Finland, Tampere 1980. 14 p. (System safety analysis bulletin no $2 / 80$ ). 